\title{
Production, recovery, and purification of recombinant 503 antigen of Leishmania infantum chagasi using expanded bed adsorption chromatography
}

\author{
Francisco Canindé de Sousa Junior ${ }^{1 *}$, Michelle Rossana Ferreira Vaz ${ }^{2}$, Carlos Eduardo de Araújo Padilha ${ }^{1}$, \\ Daniella Regina Arantes Martins ${ }^{3}$, Gorete Ribeiro de Macedo ${ }^{1}$, Everaldo Silvino dos Santos ${ }^{1}$
}

From 5th Congress of the Brazilian Biotechnology Society (SBBIOTEC)

Florianópolis, Brazil. 10-14 November 2013

\section{Background}

Visceral leishmaniasis, a disease caused by Leishmania infantum chagasi, represents a major public health problem in many areas of the world. Despite the considerable effort, there is no effective and safe vaccine for human use [1]. Some authors have reported that as much as $50 \%$ of overall costs in the biotechnology industries are related to downstream processing. Thus, the development of new and economically advantageous purification methods is a challenge [2]. Expanded bed adsorption (EBA) is an innovative chromatography technology that allows the adsorption of target proteins directly from unclarified feedstock. EBA technology combines solidliquid separation with an adsorption step in a single-unit operation, aiming at increased overall yield, reduced operational time, and less capital investment and consumables $[3,4]$. Thus, the aim of this work was to purify the 503 antigen of Leishmania i. chagasi directly from crude feedstock using EBA chromatography.

\section{Methods}

The strain of E. coli expressing 503 antigen of Leishmania $i$. chagasi was kindly provided by Dr. Mary Wilson (University of Iowa, USA) [1]. The clone was cultured in 2xTY medium supplemented with antibiotics [5]. The cultivations were carried out using a bench bioreactor with a work volume of $1.5 \mathrm{~L}$, at frequency of agitation of $400 \mathrm{rpm}$ and constant output aeration of $1 \mathrm{vvm}$. The expression of the

'Departamento de Engenharia Química, Universidade Federal do Rio Grande do Norte, Natal, RN, 59078-970, Brazil

Full list of author information is available at the end of the article recombinant protein was induced by the addition of lactose $10 \mathrm{~g} / \mathrm{L}$. Optimization of adsorption and elution conditions of 503 antigen was performed in batch mode according to two central composite designs. Then, EBA using Streamline Chelating was employed to purify 503 antigen from unclarified bacterial homogenate with a glass column $(30.0 \mathrm{~cm} \times$ $2.6 \mathrm{~cm} \mathrm{I.D)}$ and an adjustable piston, in order to minimize headspace over the fluidized bed. Analysis of the fractions was performed by Lowry method and electrophoresis on $15 \%$ polyacrylamide gels under denaturing conditions. The gels were photographed to estimate protein production, using the software ImageJ.

\section{Results and conclusions}

The batch adsorption experiment with Streamline Chelating showed that the optimal binding condition of 503 antigen was $\mathrm{pH} 8.0$ in the presence of $1.625 \mathrm{M} \mathrm{NaCl}$. The optimal elution condition for the elution of protein of interest from the adsorbent was in the presence of $600 \mathrm{mM}$ imidazole. The adsorption isothermal data of 503 antigen onto Streamline Chelating showed that the data obeyed the Langmuir adsorption isotherm. The EBA assays showed that bed height increased linearly with the linear flow velocity. The fraction recovered after the elution contained $25 \%$ of the initial amount of 503 antigen. In conclusion, EBA has been applied successfully to purify the 503 antigen from an E. coli homogenate. The EBA mode combined clarification, capture, and purification of the interesting protein in a single step process, thereby giving rise to a good product recovery. 


\section{Acknowledgements}

The authors thank the CNPq and CAPES for the financial support.

\section{Authors' details}

'Departamento de Engenharia Química, Universidade Federal do Rio Grande do Norte, Natal, RN, 59078-970, Brazil. ${ }^{2}$ Centro de Desenvolvimento

Sustentável do Semiárido, Universidade Federal de Campina Grande, Sumé, PB, 58540-000, Brazil. ${ }^{3}$ Departamento de Biologia Celular e Genética,

Universidade Federal do Rio Grande do Norte, Natal, RN, 59078-970, Brazil.

Published: 1 October 2014

\section{References}

1. Martins DR, Jeronimo SM, Donelson JE, Wilson ME: Leishmania chagasi Tcell antigens identified through a double library screen. Infect Immun 2006, 74:6940-6948.

2. Santos ES, Guirardello R, Franco TT: Preparative chromatography of xylanase using expanded bed adsorption. J Chromatogr A 2002, 944:217-224.

3. Lin DQ, Tong HF, Van de Sandt EJ, Boer PD, Golubović M, Yao SJ: Evaluation and characterization of axial distribution in expanded bed. I. Bead size, bead density and local bed voidage. J Chromatogr A 2013, 1304:78-84.

4. Yap WB, Tey BT, Alitheen NB, Tan WS: Purification of His-tagged hepatitis $B$ core antigen from unclarified bacterial homogenate using immobilized metal affinity-expanded bed adsorption chromatography. J Chromatogr A 2010, 1217:3473-3480.

5. Vaz MRF, França RLS, Andrade SSL, Sousa Junior FC, Santos ES, Martins DRA Macedo GR: Influence of culture medium on the production of eif antigen from Leishmania chagasi in recombinant Escherichia coli. Braz J Microbiol 2011, 42:1390-1396.

doi:10.1186/1753-6561-8-S4-P194

Cite this article as: Sousa Junior et al:: Production, recovery, and purification of recombinant 503 antigen of Leishmania infantum chagasi using expanded bed adsorption chromatography. BMC Proceedings 2014 8(Suppl 4):P194.

\section{Submit your next manuscript to BioMed Central and take full advantage of:}

- Convenient online submission

- Thorough peer review

- No space constraints or color figure charges

- Immediate publication on acceptance

- Inclusion in PubMed, CAS, Scopus and Google Scholar

- Research which is freely available for redistribution

Submit your manuscript at www.biomedcentral.com/submit 